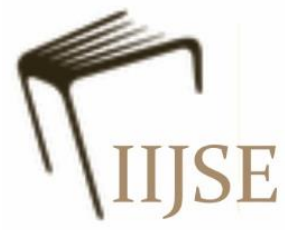

\title{
CASH WAQF LINKED SUKUK: POTENTIAL AND CHALLENGES
}

\author{
Fusthathul Nur Sasongko ${ }^{1}$ \\ Universitas Airlangga, Surabaya, Indonesia \\ fusthathul.nur.sasongko-2019@ feb.unair.ac.id \\ Tika Widiastuti ${ }^{2}$ \\ Universitas Airlangga, Surabaya, Indonesia \\ tika-w@feb.unair.ac.id \\ Muhammad Syaukin Muttaqin ${ }^{3}$ \\ Sekolah Tinggi Ekonomi dan Bisnis Islam Al-Rosyid, Bojonegoro, Indonesia \\ syaukin12@gmail.com
}

\begin{abstract}
Waqf as an instrument of Islamic economics in the modern era as it is today. Indonesia with the most Muslims in the world has a very large potential for waqf, with a nominal potential of approximately Rp. 2,000 Trillion and it would be a shame if that great potential could not be optimized as well as possible. Then CWLS is expected as an alternative instrument for optimizing the potential of waqf and examining the obstacles that will be faced. The purpose of this research is Cash Waqf Linked Sukuk as an instrument for optimizing the potential of waqf in Indonesia. CWLS is a productive cash waqf which is expected to improve the national economy. The research method used is library research where by reviewing all articles, books, and writings of experts to strengthen CWLS, you can maximize the potential of waqf in Indonesia. The results obtained are that CWLS is able to be an alternative for optimizing the potential of waqf, then the obstacles faced are the level of literacy as community insight in doing waqf and the level of religiosity of the community in doing waqf.
\end{abstract}

Keywords: CWLS, Waqf, Potential Waqf, Sukuk 


\section{INTRODUCTION}

The Muslim population in Indonesia has increased, it is noted that Indonesia is the country with the largest Muslim population in the world. In 2010, Global Religious Futures explained that the Muslim population of Indonesia reached 209.12 million or about $87 \%$ of the total population in Indonesia. Then the GRF projects that by 2020 Muslims in Indonesia will increase to 229.62 million and will continue to grow until 2050 by 256.82 million people. With a very large Muslim population, Indonesia has great potential in implementing the concepts of raising funds contained in the Qur'an, namely Zakat and Waqf.

We already know that the potential for zakat in Indonesia is very large, based on the Outlook on Zakat Indonesia, the potential for zakat in Indonesia until 2020 is 233.84 trillion rupiah, but from the collection of ZIS by BAZNAS and LAZ it is only 8.2 trillion in 2019. That is very far from expectations considering the Muslim population in Indonesia is very high. Then in the aspect of waqf in February 2020, BWI released that Indonesia has a total potential of 2,000 trillion which is divided into two fields, namely the first, the potential area of waqf land is around 420,000 hectares and the second is the potential for cash waqf of around 280 trillion, but in reality in 2017 only about 400 billion have just been collected.

It takes innovations to maximize this enormous potential. Cash Waqf Linked Sukuk (CWLS) is present as a form of government innovation in maximizing the potential of waqf in Indonesia. The CWLS program was launched by Bank Indonesia together with the Islamic Development Bank (IDB) at the annual meeting (IMF-World Bank) Bali (12 - 14 October 2018). In the National Waqf Caring Day (NWCD) CWLS activities supported by 9 institutions that donated money, the funds collected were Rp. 13.5 billion (Kontan.co,id, 2019). After one year the CWLS program was launched, the data recorded on the official website of the bank that was officially appointed to collect CWLS funds directly from the public and corporations was still quite low, reaching only Rp. 55,873,851 (collected by Bank BNI Syariah with a total wakif of 64 people). listed on the website)) and Rp. $88,382,251$ (collected by Bank Muamalat Indonesia listed on the website)), from the target in 2019 of Rp. 50 Billion. So CWLS as a potential in order to maximize and also the challenges in running it will be discussed in this paper. 


\section{REVIEW OF LITERATURE}

\section{Cash Waqf}

Definition ofendowment in terms of Personality ', the general endowment is a kind of gift that the implementation is done by retaining (ownership) of origin (tahsibul Ashli), and then make its benefits are generally accepted. Tahsibul ashli is to hold goods to be waqf so that they are not inherited, sold, donated, pawned, rented, and the like. How to use it by using according to the will of wakif / without compensation (Rusdian, 2018). The definition of waqf according to Law no. 41 of 2004 concerning Waqf Article 1 paragraph (1), namely "Waqf is a legal act of wakif to separate and/or surrender part of his property to be used forever or for a certain period of time in accordance with its interests for the purposes of worship and/or public welfare according to sharia."

The Indonesian Ulema Council (MUI) has defined waqf and cash waqf, according to the MUI waqf is to hold assets that can be used, without destroying their original physical form ( 'ain) or origin, by not taking any action against assets (such as selling, giving, or inheriting assets). That it can be exhausted, while cash waqf in its fatwa on the permissibility of waqf on May 11, 2002 which states that cash waqf (cash waqf / waqf al nuqud) is waqf carried out by a person, group of people, institutions or legal entities in the form of cash, including in this sense are securities. This definition was later strengthened by the issuance of Law no. 41 of 2004 and PP No. 42 of 2006 concerning waqf which states that money is part of waqf objects.

According to Mauluddin and Asmak (2019) in their writings they explain that fatwa Number 2 of 2002 by the MUI regarding the rules for cash waqf is jawaz (permitted). MUI has provided guidelines for the implementation of cash waqf so that it is carried out according to sharia. Guidelines for implementing waqf cashin Indonesia include: a) Cash waqf can only be given and used in things that are permitted by sharia; b) The value of thecurrency waqf cashmust be guaranteed to be the main currency. tainted and cannot be sold, donated or inherited.

\section{Waqf and Sukuk}

According to the DSN MUI fatwa No. 32 of 2002 Sukuk (sharia bonds) are longterm securities based on sharia principles issued by the Issuer to the holders of Syari'ah 
Bonds which require the Issuer to pay income to the holders of the Syari'ah Bonds in the form of profit sharing/ margin/fee, as well as repaying bond funds at maturity".

Sukuk or Islamic bonds originated from bonds that are identical with interest, also contradictory because interest is one aspect that is highly avoided by Muslim communities. Getting to know the bond that was originally known asinstrument fixed income because it provides a coupon with fixed interest (fixed) during the tenor. Then also developed "bonds with floating interest coupons (floating)" so that the interest received by bondholders is no longer fixed. In the case of Islamic bonds, the coupons given are no longer based on interest, but profit sharing or margin/fee.

It is interesting to note that the Fatwa of the National Syari'ah Council No: 32/DSNMUI/IX/2002 provides an initial consideration that the bonds that have been defined so far (conventionally) are still not in accordance with sharia. Therefore, bonds that are justified according to sharia, namely bonds that are based on sharia principles.

In subsequent developments, bonds in Islam are known as "sukuk". Sukuk is a new term introduced as a substitute for the term Islamic bonds (Islamic Bonds). Sukuk are certificates that show the same value after closing the subscription, receipt of the value of the certificate and putting it to use as planned, ownership of shares and rights to visible assets, uses and services, and equity on the mentioned project or equity on certain investment activities ( AAOIFI, 2002).

This waqf-based sukuk is an integration of waqf with sukuk. In fiqh, this waqfbased sukuk is called the al-intifa' sukuk. Waqf assets are used as the underlying (support) for the issuance of sukuk. Where sukuk is a certificate of equal value which is proof of ownership that is not shared over an asset, benefit rights, and services or ownership of a particular project or investment activity (Khaerul, 2013).

The issuer of this waqf-based sukuk can be from various market players and even the private sector. Even in terms of cost, the issuance of waqf-based sukuk will be more efficient, because the underlying asset in the form of land is provided by the waqf manager (nadzir), both waqf managed by the government and the private sector. 


\section{Cash Waqf Linked Sukuk}

Cash Waqf Linked Sukuk is a product of innovation waqf sukuk, which is a form of social investment in Indonesia where cash waqf is collected by the Indonesian Waqf Board as Nadzir through BNI Syariah and Bank Muamalat Indonesia as a Sharia Financial Institution Recipient of Cash Waqf (LKSPWU) will be managed and placed on the State Sukuk or SBSN (State Sharia Securities) instrument issued by the Ministry of Finance (Kemenkeu).

The objectives of developing Cash Waqf Linked Sukuk are: a) Part of efforts to develop and innovate in the field of Islamic finance and social investment in Indonesia; b) Facilitating cash waqf to be able to invest cash waqf in a safe financial instrument, namely state sukuk; c) Encouraging the consolidation of Islamic social funds to finance various social projects and programs (not government projects/programs through APBN/APBD; d) Part of the efforts to diversify investors and SBN instruments; e) Support the development of the sharia financial market, particularly the cash waqf industry; f) Encouraging diversification of the sharia banking business through optimizing the role of LKS PWU.

The basic concepts of Cash Waqf Linked Sukuk are as follows; a) This is a tangible manifestation of the strong support and commitment from the authorities, in this case BWI, Ministry of Finance, Ministry of Religion, and BI, towards development and innovation efforts in the field of Islamic finance and social investment in Indonesia; b) The government will issue a series of State Sukuk "Sukuk Waqf" to facilitate BWI and money waqf to be able to invest cash waqf in a safe financial instrument, namely the State Sukuk; c) Through CWLS, cash waqf, both temporary and permanent, will be consolidated and optimized to finance various social projects/activities, which include: 1) Construction and development of waqf assets such as madrasas, mosques, health clinics, Islamic boarding schools, and other social infrastructure facilities financed from discounted waqf sukuk; 2) Implementation of non-physical social programs, such as social programs for orphans and the poor, free health services for the poor, economic empowerment of low-income communities, and other social programs and financed from monthly coupons for waqf sukuk; 3) The management and implementation of these social projects/activities are carried out by social institutions appointed by BWI, and are not government projects/activities (Paul and Rachmad, 2020). 


\section{RESEARCH METHOD}

Method used in this study is qualitative research using aapproachlibrary research, where the data used are secondary from existing research literature and by reviewing studies from books, journals, articles and other literature, in order to conduct analysis. indepth information about Cash Waqf Linked Sukuk as an innovation in maximizing the potential of waqf and the obstacles that will be faced.

\section{RESULTS AND DISCUSSION}

Potential of waqf in Indonesia is very large, the Indonesian Waqf Board has released the potential of waqf in February 2020 the total potential of waqf reaches Rp. 2,000 Trillion with details of waqf in the form of 420,000 hectares of land and cash waqf of Rp. 180 trillion (validnews.id, feb 2020). In this data, we can see how great the potential of waqf and waqf is not only about land which is identical to the construction of mosques, schools or other social places. But waqf has offered, namely productive waqf in the form of cash waqf which can be managed and can create profits that can be much greater.

Cash waqf emerged as an alternative to facilitate waqf, previously in his writing, Suganda (2014) explained that cash waqf are funds collected by waqf managers (nadzir) through the issuance of cash waqf certificates purchased by the public. Cash waqf can also be interpreted as waqf property in the form of money or securities managed by institutions (banks or sharia financial institutions) whose profits will be donated, provided that the capital cannot be reduced for alms, while the collected waqf funds can then be rolled out and invested by nadzir into various halal and productive business sectors, so that the profits can be utilized for the development of the people and the nation as a whole.

The Fatwa Commission of the Indonesian Ulema Council has issued a fatwa regarding cash waqf which states that: a) (Cash waqfcash waqf or waqf al-Nuqud) is a waqf carried out by a person, group of people, institutions or legal entities in the form of cash; b) Included in the definition of money are securities; c) Moneylegal (waqf isJawaz); d) Cash waqf can only be channeled and used for things that are permitted by syar'I; and e) The principal value of cash waqf must be guaranteed for its sustainability, it may not be sold, donated and or inherited. 
The product of cash waqf is sukuk waqf, although Sukuk and waqf are two different instruments but are collaborated into one through waqf sukuk with the aim of obtaining a greater benefit value. Sukuk built on ijarah contracts that have a business nature, while waqf built on social contracts have no yield.

The intended waqf sukuk are sukuk based on an ijarah contract, because ijarah has good flexibility and potential, the characteristics of ijarah are that the sukuk holder jointly bears the risk of the assets, the costs associated with ownership and the proceeds from the rent are distributed to the sukuk holders. The emergence of additional costs or unexpected costs on leased assets as well as the possibility of failure and absolute profits remain, although many investors respond that profits remain absolute contrary to the Islamic financial system.

Then came Cash Waqf Linked Sukuk (CWLS) a form of the Government's seriousness in supporting waqf and make it easier for people to do waqf. With the mechanism offered by CWLS (Paul and Razhmad, 2020).

Figure 1

CWLS Prosedure

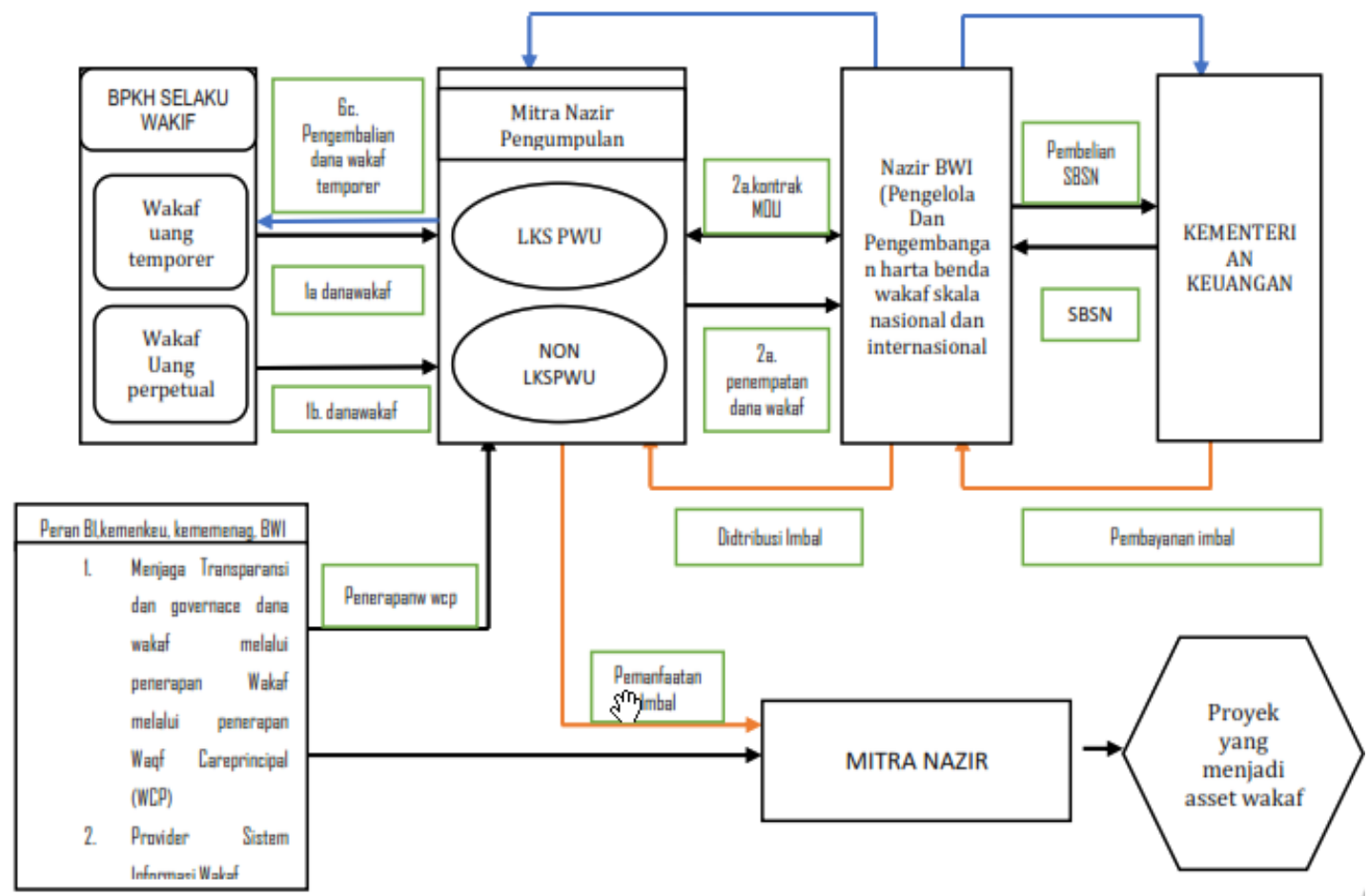


Image Explanation: a) Wakif waqf his money through nadzir partners or LKSPWU to nadzir BWI with two options: 1) Cash waqf for a certain period of at least 5 million for a minimum period of 5 years. 2) Money Waqf Forever; b) Wakif deposit cash waqf funds into the account of nadzir partners at LKS-PWU and afterwards make a Waqf Pledge in front of a bank official who is appointed as the Official Making the Waqf Pledge Deed (PPAIW) as outlined in the Waqf Pledge Deed. In the event that the wakif cannot be present before PPAIW, the wakif may appoint a representative or proxy; c) Deposits of money waqf funds from wakif are placed in a wadiah account in the name of a nadzir partner before being placed into aaccount nadzir BWI; d) By BWI if the cumulative number of allpartners nadzir has reached 50 billion, BWI transfers the money waqf funds that are in the nadzir partner's account to the BWI account at LKS PWU as wadi'ah; e) The 50 billion cash waqf funds that have been collected in the BWI account are purchased by SBSN issued by the Ministry of Finance for a certain period of time; f) Cash waqf funds that have been purchased by the Ministry of Finance of State Sharia Securities (SBSN) or Sukuk are used to finance government projects in the field of public services; g) The Ministry of Finance pays SBSN or State Sukuk coupons to nadzir BWI in accordance with the contract; h) Nadzir BWI coupons for SBSN or State Sukuk after deducting rights nadzir's $10 \%$ of and management fees, are channelled through partners nadzir to finance the construction of waqf assets or public facilities such as madrasas, hospitals, and others; i) The Ministry of Finance returns cash waqf funds to BWI after the SBSN or State Sukuk matures; j) BWI ordered nadzir partners and LKS-PWU to return cash waqf funds for a certain period of time to wakif; k) The return of cash waqf funds to the wakif through an operational bank that has been appointed by BWI; 1) The Ministry of Religion and the Indonesian Waqf Board supervise the sukuk-linked money waqf program.

And in Paul and Rachmad's writings, they explain the advantages of Cash Waqf Linked Sukuk, including: a) There is facilitation for cash waqf so that it can be used for productive activities; b) Placement of cash waqf in a safe and risk-free instrument, namely state sukuk; c) Funds will be returned $100 \%$ for wakif at the maturity of SBSN. d) The results of the waqf sukuk investment are used for the formation of new waqf assets and the financing of various social activities; e) Candidates for wakif with a certain amount of cash 
waqf can propose projects/social activities to be carried out/financed; f) BWI is exempt from taxation, so investment returns are competitive.

CWLS is an alternative instrument of waqf in the modern era because people rarely own assets in the form of land and other immovable objects, now most people have assets in the form of cash because nowadays young people and society in general are literate about investment. CWLS is present as an investment instrument that can provide social effects to improve the national economy.

CWLS comes not only smooth, its existence is still common and causes obstacles in its implementation. According to an article by Hiyanti, et al (2020) explaining that in offering CWLS as a solution in optimizing waqf, there are obstacles, namely the literacy and religiosity factors.

The results of the discussion in the paper of Hiyanti, et. al. First, literacy is a constraint for the community which is still low, because with low waqf literacy, it will reduce motivation/intensity in using CWLS as a charity medium. Where in Amirul Faiz (2012) literacy Literacy becomes an important thing that affects someone to waqf, based on the results of a survey that has been carried out stating that cash waqf and sukuk are still low, namely at values 2 and 3 of the 5 scales listed in the questionnaire. The results of this survey are also in line with the findings of researchers in the field at LKSPWU in big city branches in Indonesia, which shows that the delivery of information about CWLS from the LKSPWU is still not optimal.

Then the second level of religiosity is still low. According to Lamman and Gabler (2012) that religiosity is an important social determinant in charity. This religiosity is influential from within and can encourage someone to do charity, where the high religiosity of the community will increase the intention of waqf in CWLS, then the low level of community religiosity will reduce the motivation/intention of waqf in CWLS.

\section{CONCLUSION}

Cash Waqf Linked Sukuk (CWLS) is one of the alternative instruments for optimizing the potential of waqf in Indonesia. Bank Indonesia issuing CWLS is a form of the government's seriousness in exploring the potential of waqf found in Muslim communities in Indonesia, where CWLS is a form of productive waqf in the form of cash 
waqf which is movable which is not only in the form of charitable activities but can increase the national economy.

There are two obstacles in the implementation of CWLS as a waqf instrument, namely the first level of literacy, because literacy is very important in people's insight in starting CWLS waqf and the level of community literacy about CWLS is still low. Then the second is the level of religiosity of the community, because the level of religiosity greatly affects the community in doing waqf, if religiosity is low then there will be no sense of wanting to do waqf.

The author's suggestion for the government to continue to socialize about CWLS is to introduce that waqf is not only about land and buildings, but also through cash waqf, one example of which is CWLS. And appealed to the public about the importance of charity for economic progress by means of productive endowments.

\section{REFERENCES}

Accounting and Auditing Organization for Islamic Financial Institution (AAOIFI), 2002.

General, Khaerul. (2013). Sharia Capital Market and Sharia Capital Market Practices. Bandung: Faithful Library.

Hiyanti, Hida et al. (2020). The Influence of Literacy and Religiosity on the Intention of Waqf in Cash Waqf Linked Sukuk (CWLS). JIMEA | MEA Scientific Journal Management, Economics, and Accounting 4(3), 2020. 493-507.

Lammam, C. \& Gabler, N. (2012). Determinants of charitable giving: A review of the literature. Fraser Forum March/April. 12-15.

Mauluddin, Muhammad Ikhwan and Asmak, Ab. Rahman. (2019). Cash Waqf From the Perspective of the Indonesian Ulema Council (MUI) and the Scholars of Aceh: An Analysis. New Developments in Islamic Economics, 49-66.

Paul, Vienna and Rachmad Faudji. (2020). Cash Waqf Linked Sukuk in Optimizing the Management of Movable Waqf (Money). JIMEA Scientific Journal of MEA (Management, Economics, and Accounting), 4(2), 2020. 1-18.

Rusydiana, Aam Slamet. (2018). Application of Interpretive Structural Modeling for Cash Waqf Development Strategy in Indonesia. Journal of Islamic Economics and Business, 4(1), January-June 2018. 1-17 Fatwa of the National Sharia Council of the Indonesian Ulema Council No: 32/DSN-MUI/IX/2002. 
Suganda, Asep Dadan. (2014). The concept of cash waqf. Journal of Islamic Economics. 115. 